\title{
Efficacy of Biological and Chemical Treatments for Control of Fusarium Root and Stem Rot on Greenhouse Cucumber
}

\author{
S. Rose and M. Parker, Former Graduate Students, and Z. K. Punja, Professor, Center for Environmental Biology, \\ Department of Biological Sciences, Simon Fraser University, Burnaby, British Columbia, V5A 1S6, Canada
}

\begin{abstract}
Rose, S., Parker, M., and Punja, Z. K. 2003. Efficacy of biological and chemical treatments for control of Fusarium root and stem rot on greenhouse cucumber. Plant Dis. 87:1462-1470.

Potential disease control methods were evaluated against root and stem rot of cucumber ( Сисиmis sativus) caused by Fusarium oxysporum f. sp. radicis-cucumerinum. Crab/shrimp shell chitin; three composted media; the biological control agents Pseudomonas chlororaphis strain 63-28, Trichoderma harzianum (RootShield Drench), Streptomyces griseoviridis (Mycostop), Gliocladium catenulatum (Prestop WP, Prestop Mix), and Trichoderma (Gliocladium) virens (SoilGard); and the fungicides thiram or benomyl were added at seeding time followed by inoculation with the pathogen. The addition of chitin $(4 \%$, vol/vol) to a peat-based medium significantly $(P \leq 0.05)$ enhanced seedling growth, increased soil $\mathrm{pH}$, and reduced $F$. oxysporum $\mathrm{f}$. sp. radicis-cucumerinum populations, but the severity of disease was increased. The addition of composted media (greenhouse compost, windrow composted dairy solids, and vermi-composted dairy solids) to the seeding cavity in a rock wool block medium, followed $48 \mathrm{~h}$ later by inoculation with $F$. oxysporum f. sp. radicis-cucumerinum, reduced seedling mortality when measured after 37 days. Greenhouse compost was significantly $(P \leq 0.05)$ more suppressive than the other two composts, and the suppression was partially eliminated by sterilization of the compost. The biological control agent $G$. catenulatum (formulated as Prestop WP and Prestop Mix) significantly reduced seedling mortality when it was applied at seeding $24 \mathrm{~h}$ prior to inoculation with the pathogen in the rock wool block medium. None of the other biological control agents reduced disease incidence when compared with control plants under these experimental conditions. Pseudomonas chlororaphis and the fungicide thiram both significantly reduced plant mortality at 17 and $24^{\circ} \mathrm{C}$ when pathogen-infested seed was treated, or when bacteria-treated and fungicide-treated seed were planted into pathogen-infested peat medium at $24^{\circ} \mathrm{C}$. Under semicommercial propagation conditions, treatments consisting of Prestop WP, RootShield Drench, Mycostop, and windrow composted dairy solids reduced the severity of disease caused by $F$. oxysporum f. sp. radicis-cucumerinum in two out of three trials. The efficacy of the biological control agents was affected by seasonal differences in growing conditions, which affected the incidence and severity of the disease. The results from this study indicate that several different approaches can be used at seeding to control Fusarium root and stem rot on greenhouse cucumber.
\end{abstract}

Fusarium root and stem rot of greenhouse cucumber (Cucumis sativus L.), caused by Fusarium oxysporum f. sp. radicis-cucumerinum D.J. Vakalounakis, was first observed in a few commercial greenhouses in the Fraser Valley of British Columbia (B.C.), Canada, during the 1995 crop season (51). The pathogen has since spread to many greenhouses in the province and continues to be a recurring problem for growers (51). The first published report of this disease was from the island of Crete, Greece, during the 1989-90 crop season (58). The pathogen subsequently spread to most cucumber growing regions of Crete, with severe crop losses occurring only 3 years after it was first reported (58).

Corresponding author: Z. K. Punja

E-mail: punja@sfu.ca

Accepted for publication 20 July 2003.

Publication no. D-2003-1007-01R

(C) 2003 The American Phytopathological Society
There are recent occurrences of this pathogen in Alberta and Ontario, Canada, as well as in Israel, France, and the United States (Z. K. Punja, unpublished data). Symptomology and disease development have been described by Vakalounakis (58) and Punja and Parker (51). Infected roots, crown, and stem tissues are rotted and contain mycelia and spore masses of the pathogen (51). Potential control methods for this new disease have not been identified, and commercial growers presently have few options.

In general, methods for control of Fusarium wilt, root, and stem rots on greenhouse crops have emphasized development of resistant cultivars and avoidance of primary inoculum. Breeding for resistance, however, can be difficult if resistance genes have not been identified, as is the case for Fusarium root and stem rot of cucumber. Pavlou et al. (47) recently identified disease-resistant cucurbit rootstocks onto which susceptible cucumber varieties could be grafted. Reduction of primary inoculum (e.g., on seed, planting stock, and in growing media) is an alternative option, through the use of fungicides, heat or chemical treatments, disease-free planting stock, sanitation, and fumigation (1). Several reports have also demonstrated the successful use of biological control agents (mostly bacteria and fungi) against diseases caused by various formae speciales of $F$. oxysporum on a range of hosts $(11,28,31,34,36,41)$ grown under greenhouse or field conditions. Similarly, composts and chitin amendments have been reported to reduce the impact of diseases caused by $F$. oxysporum on several hosts $(7,9,10,37,42,48,54,56,57)$.

At present, there are no fungicides registered for use in B.C. on cucumber to control Fusarium root and stem rot. Addition of biological control agents or other amendments to the growing medium may offer an alternative disease control strategy if efficacy data were available to support their use. The objectives of this study were to evaluate the effects of amendments to the growing medium (either peat or rock wool), using crab/shrimp shells, composted media, commercially available biological control agents, and fungicides, on development of Fusarium root and stem rot on cucumber. Since primary infection has been reported to occur during the propagation stage of cucumber crops (within 30 days after seeding) (51), disease control strategies were targeted to prevent seedling infection and reduce pathogen growth early in the growing season.

\section{MATERIALS AND METHODS}

Pathogen inoculum. Isolates 16 and Fern of $F$. oxysporum f. sp. radiciscucumerinum were recovered from the roots of infected cucumber plants (Long English type) grown in commercial greenhouses in B.C., Canada. The roots were washed in water, surface-sterilized in $70 \%$ ethanol for $30 \mathrm{~s}$, and then plated onto $F$. oxysporum-selective agar medium (27) in $100 \times 15 \mathrm{~mm}$ petri dishes. Dishes were incubated under ambient laboratory conditions $\left(20\right.$ to $23^{\circ} \mathrm{C}$ ) under fluorescent lights (12-h photoperiod) for approximately 10 days, after which time the pathogen was transferred to acidified potato dextrose agar (APDA) containing (per liter) $4 \mathrm{ml}$ of $25 \%$ lactic acid (final $\mathrm{pH} \mathrm{4.0)}$ and $200 \mathrm{mg}$ of ampicillin (Sigma Chemical Co., St. Louis, MO). After 2 weeks, inoculum of $F$. oxysporum f. sp. radicis-cucumerinum was obtained by flooding the colony with $10 \mathrm{ml}$ 
of sterile double-distilled water, and the mycelia plus spores were scraped off using an inoculating loop. The suspension was not filtered since aerial mycelial growth on APDA was minimal and spores were readily formed in sporodochia on the agar surface (51). The spore suspension (containing macroconidia and microconidia) was diluted with sterile double-distilled water to the desired concentration as determined using a hemacytometer.

Plant growth conditions. The evaluation of potential disease control methods for Fusarium root and stem rot on cucumber was conducted using two widely used plant growth substrates in cucumber production: peat medium and rock wool blocks. Cucumber seeds (cv. Corona, Escape, or Mustang, all highly susceptible to F. oxysporum f. sp. radicis-cucumerinum) were planted directly into sterilized Sunshine Mix \#1 medium (SM) containing 70 to $80 \%$ Canadian sphagnum peat moss, perlite, dolomitic limestone, gypsum, and wetting agent (Sun Gro Horticulture Inc., Bellevue, WA) in 8.5-cm-diameter pots and maintained either on a bench top in a growth room (with a $12-\mathrm{h}$ photoperiod and a temperature range of 20 to $23^{\circ} \mathrm{C}$ ) or in a growth chamber (with a 16-h photoperiod and temperature of $24 \pm 2{ }^{\circ} \mathrm{C}$ ) based on space requirements. Alternatively, a rock wool block system was used (Fig. 1) in some experiments to simulate commercial propagation conditions. Seeds were placed in a seeding cavity $\left(1.8 \mathrm{~cm}^{3}\right)$ cut into a 3.5 $\times 3.5 \mathrm{~cm}^{2}$ rock wool block, which was then filled with vermiculite, SM, or compost. Each block was placed inside an inverted Styrofoam coffee cup which was filled with $200 \mathrm{~cm}^{3}$ of yellow cedar sawdust (obtained from Robinson Farms in Abbotsford, B.C.). A saucer was placed under the cup to retain water (Fig. 1). The plants were maintained under growth room conditions with supplemental lighting, fertilized with a nutrient solution recommended by the B.C. Ministry of Agriculture, Fisheries and Food for commercial cucumber production (3), and watered three times a week.

Effect of inoculation time on disease development. To determine the age at which cucumber seedlings are most susceptible to infection by $F$. oxysporum f. sp. radicis-cucumerinum in the rock woolsawdust system (Fig. 1), $1 \mathrm{ml}$ of inoculum $\left(10^{6}\right.$ spores per $\left.\mathrm{ml}\right)$ was applied as a drench to the seeding cavity of rock wool blocks at $1,3,5,7$, or 10 days following seeding. Plant mortality was recorded from 10 plants per treatment after 37 days of incubation under growth room conditions. The experiment was repeated three times.

Effect of crab/shrimp shells. Crab/ shrimp shells, a by-product of the shellfish processing industry provided by Stephen $\mathrm{Ng}$ (International Chitin, Richmond, B.C.), were predigested by treatment in a fermenter with bacterial exo-chitinases to produce a viscous paste containing $\mathrm{N}$ acetylglucosamine residues, which was added to SM at a rate of $4 \%$ (vol/vol). An analysis of the paste showed it contained $6.4 \% \mathrm{~N}, 2 \% \mathrm{Ca}, 0.26 \% \mathrm{P}, 0.11 \% \mathrm{~K}, 0.17 \%$ $\mathrm{Na}$ (dry weight basis), and a wide range of micronutrients (S. Ng, unpublished data). The amended peat was moistened to saturation and incubated for 3 days at ambient temperature $\left(20\right.$ to $\left.23^{\circ} \mathrm{C}\right)$. Changes in $\mathrm{pH}$ of the substrate after amendment were monitored every 3 to 4 days from samples (2:1 mix of medium:water) and compared with unamended controls over a 30-day period. Inoculum of $F$. oxysporum f. sp. radicis-cucumerinum $\left(20 \mathrm{ml}\right.$ of $10^{5}$ spores per $\mathrm{ml}$ ) was added to $250 \mathrm{~cm}^{3}$ of SM medium 3 days after the initial amendment. Changes in inoculum density were estimated every 3 to 4 days by diluting $1 \mathrm{~cm}^{3}$ of the medium to $10^{-3}$ in sterile distilled water and plating $0.5 \mathrm{ml}$ of the final dilution onto Komada's medium (27) (in three replicates) and enumerating the colonies after 7 days of incubation. Cucumber seeds which had been pregerminated on moistened filter paper for 5 days were planted into the amended SM medium containing inoculum of $F$. oxysporum $\mathrm{f}$. sp. radiciscucumerinum as described above. Control treatments included plants grown in amended medium without pathogen inoculum, plants grown in nonamended medium with inoculum, and noninoculated plants grown in nonamended medium. Plant height measurements (from the soil surface to the growing tip), fresh weights (shoots and leaves), and dry weights (shoots and leaves) were obtained after 24 days, and disease incidence was expressed as percentage of symptomatic plants (dead or wilting) from eight plants per treatment. The experiment was repeated twice.

Effect of composts. Three composts were evaluated for disease suppressive activity: (i) greenhouse compost (derived from organic greenhouse wastes comprised of leaves, stems, and fruit of tomato [ $L y$ copersicon esculentum Mill.] and sawdust medium) prepared in a pilot scale in-vessel composting system for 30 days with maximum temperature of $65^{\circ} \mathrm{C}$, then cured for 3 months, provided by B. Fraser of Vision Envirotech International Co. Ltd. (Delta, B.C.); (ii) windrow-composted dairy solids; and (iii) vermi-composted dairy solids. Both composts (provided by R. Utkhede, Agriculture and Agri-Food Canada, Agassiz, B.C.) were prepared from solids obtained by passing liquid manure through a liquid-solid separator (26). The windrow-composted dairy solids were composted by the periodic turning of a windrow pile $(10 \times 3 \times 1.5 \mathrm{~m}$ high $)$ for 12 weeks on a concrete floor in an openaired building followed by curing for at least 6 months (26). The vermi-composted dairy solids were composted by the incorporation of earthworms (Eisenia fetida) into a $3 \times 11 \mathrm{~m}$ worm bed for 14 weeks
(26). Analysis of the greenhouse compost (Vision Envirotech International Co. Ltd., Delta, B.C.) showed it had a pH of 7.0 to 8.0, $\mathrm{EC}$ of $2.5 \mathrm{mS} / \mathrm{cm}, \mathrm{C} / \mathrm{N}$ ratio of $21.9: 1$, CEC of 120 to 170 meq per $100 \mathrm{~g}, 2 \%$ total $\mathrm{N}, 0.2 \% \mathrm{P}, 1.5 \% \mathrm{~K}$, a bulk density of 300 $\mathrm{kg} / \mathrm{m}^{3}$, and a total porosity of $73 \%$. The characteristics of the other two composts were described by Kannangara et al. (26). Windrow-composted dairy solids had a $\mathrm{pH}$ of $7.9, \mathrm{EC}$ of $1.8 \mathrm{mS} / \mathrm{cm}$, and $\mathrm{C} / \mathrm{N}$ ratio of 21:1 (26). Vermi-composted dairy solids had a $\mathrm{pH}$ of $8.0, \mathrm{EC}$ of $0.65 \mathrm{mS} / \mathrm{cm}$, and $\mathrm{C} / \mathrm{N}$ ratio of $24: 1$ (26).

A cucumber seed was placed in the seeding cavity of each rock wool block as described above and covered with $2.5 \mathrm{~cm}^{3}$ of the appropriate compost. After $48 \mathrm{~h}, 1 \mathrm{ml}$ of $F$. oxysporum f. sp. radiciscucumerinum inoculum $\left(1 \times 10^{6}\right.$ spores per $\mathrm{ml}$ ) was added to the seeding cavity of each block. Seedlings were initially maintained in the growth room under dim light (intensity of $0.9 \pm 0.4 \mu \mathrm{E} / \mathrm{m}^{2} / \mathrm{s}$ ) for 10 days, and then maintained under a 24-h photoperiod (light intensity of $95.8 \pm 13.6$ $\mu \mathrm{E} / \mathrm{m}^{2} / \mathrm{s}$ ) for an additional 10 days. The plants were then moved to a polyethylenecovered chamber with a 24-h photoperiod (light intensity of $100.3 \pm 13.6 \mu \mathrm{E} / \mathrm{m}^{2} / \mathrm{s}$ ) at $25 \pm 2{ }^{\circ} \mathrm{C}$ and relative humidity of $40 \pm 2 \%$. These environmental conditions were found in preliminary experiments to promote damping-off and root and stem rot due to $F$. oxysporum f. sp. radiciscucumerinum without the requirement for wounding of roots (unpublished data).

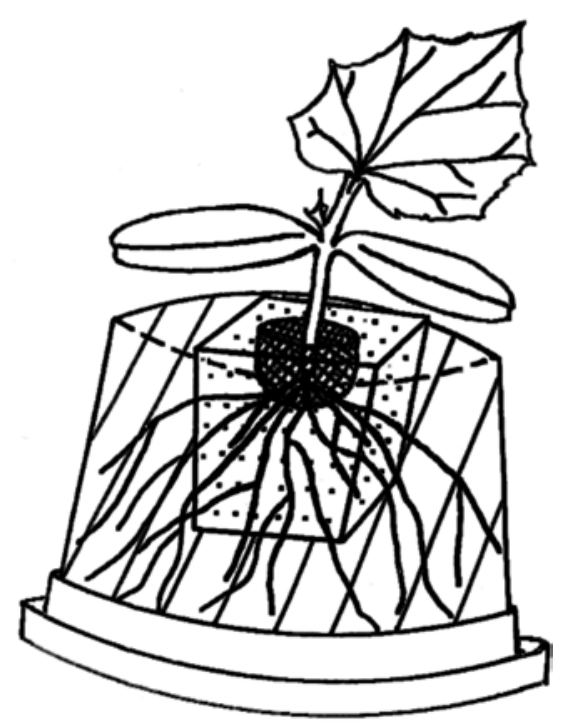

Fig. 1. Rock wool block system used to simulate commercial cucumber propagation conditions. Each cucumber seed was placed in a 1.8 $\mathrm{cm}^{3}$ germination cavity (shaded area) cut into a $3.5 \times 3.5 \mathrm{~cm}$ rock wool block, which was then filled with Sunshine Mix \#1, vermiculite, or compost, or received a biological control agent. Blocks were contained in inverted Styrofoam coffee cups, which were filled with $200 \mathrm{~cm}^{3}$ of yellow cedar sawdust. Saucers were placed under cups to retain water. 
Plant mortality (expressed as a percentage of dead plants), plant height (from the base of the rock wool block to the growing tip of the plant), and fresh weights of shoots and leaves were recorded from 10 plants of each compost treatment 37 days after seeding. Sterilized compost (autoclaved at $121^{\circ} \mathrm{C}$ for $30 \mathrm{~min}$ on two successive days) was also included for comparison. The experiment was conducted three times.

To determine the effect of greenhouse compost on $F$. oxysporum f. sp. radiciscucumerinum population levels, sawdust samples $\left(1 \mathrm{~cm}^{3}\right)$ surrounding the rock wool blocks were taken at weekly intervals from 2 to 5 weeks after seeding and compared with control treatments with SM. Samples were taken arbitrarily from three replicate cups, diluted to $10^{-2}$, and $1-\mathrm{ml}$ aliquots were plated onto each of two replicate plates of Komada's medium. Colonies were enumerated after 3 days of incubation at room temperature.

Effect of seed treatment with bacteria or fungicide. A liquid formulated suspension $\left(10^{10}\right.$ cells per $\left.\mathrm{ml}\right)$ of Pseudomonas chlororaphis strain 63-28 (provided by E. Pedersen, Ecoscience Inc., San Diego, CA) was evaluated as a cucumber seed treatment for control of $F$. oxysporum f. sp. radicis-cucumerinum. Pathogen inoculum was first applied to cucumber seed at $10^{4}$ spores per $\mathrm{ml}$, as described by Punja and Parker (51). The inoculated seeds were airdried on a filter paper (Whatman International Ltd., Kent, UK) in $100 \times 15 \mathrm{~mm}$ petri dishes for 4 days and then immersed in a bacterial suspension of $P$. chlororaphis $\left(10^{8}\right.$ cells per $\mathrm{ml}$ ) for $10 \mathrm{~min}$, and dried for $24 \mathrm{~h}$. The seeds were then planted into 8.5cm-diameter pots containing SM medium (1 seed per pot). Cucumber seeds pretreated commercially with thiram (50 WP, $4.5 \mathrm{oz}$ per $100 \mathrm{lb}$ seed, Gustafson LLG, Plano, TX) were also immersed for 5 to 10 min in a suspension of $F$. oxysporum $\mathrm{f}$. sp. radicis-cucumerinum $\left(10^{4}\right.$ spores per $\left.\mathrm{ml}\right)$, air-dried for 5 days, and planted in SM medium. Bacteria-treated and thiramtreated seeds were also planted into pathogen-infested SM medium which was prepared by adding $20 \mathrm{ml}$ of a suspension of F. oxysporum f. sp. radicis-cucumerinum $\left(10^{5}\right.$ spores per $\left.\mathrm{ml}\right)$ to $250 \mathrm{~cm}^{3}$ of $\mathrm{SM}$ and maintaining the inoculated medium at 20 to $23^{\circ} \mathrm{C}$ for 7 days. Treated seeds were planted into pots ( 1 seed per pot), which were placed in a growth chamber set at 24 $\pm 2^{\circ} \mathrm{C}$ with a 16 -h photoperiod. Plant mortality was evaluated after 30 days from 10 plants per treatment. Control plants were inoculated with the pathogen alone, bacteria alone, or were not inoculated. The experiment was conducted twice.

Evaluation of commercial biological control agents. Trichoderma harzianum strain T-22 (KRL-AG2) (RootShield Drench, BioWorks Inc., Geneva, NY), Streptomyces griseoviridis strain K61 (Mycostop, Verdera Oy, Helsinki, Finland),
Gliocladium catenulatum strain J1446 (Prestop WP and Prestop Mix, Verdera Oy, Helsinki, Finland), and Trichoderma (Gliocladium) virens strain GL-21 (SoilGard, Thermo Trilogy Corp., Columbia, MD) were evaluated for their effects on disease development caused by $F$. $o x$ ysporum $\mathrm{f}$. $\mathrm{sp}$. radicis-cucumerinum in the rock wool block system. Vermiculite was used as the germination medium. Cucumber seeds were placed in the seeding cavity of each rock wool block followed immediately by application of the biocontrol agents at recommended label rates. The following were applied as drenches: RootShield (0.9 g/liter) at $5 \mathrm{ml}$ per plant, Mycostop ( $1 \mathrm{~g} /$ liter $)$ at $20 \mathrm{ml}$ per plant, Prestop WP (10 g/liter) at $15 \mathrm{ml}$ per plant, and Prestop Mix (10 g/liter) at $15 \mathrm{ml}$ per plant. Granules of SoilGard were mixed directly into the vermiculite $(0.6 \mathrm{~g} / \mathrm{liter})$ and 2.5 $\mathrm{cm}^{3}$ of the mix was placed in the seeding cavity. After $24 \mathrm{~h}, 1 \mathrm{ml}$ of inoculum of $F$. oxysporum f. sp. radicis-cucumerinum $\left(10^{6}\right.$ $\mathrm{CFU} / \mathrm{ml}$ ) was added to each plant. Benlate (benomyl, $50 \mu \mathrm{g}$ a.i./ml, $5 \mathrm{ml}$ per plant, E.I. Du Pont de Nemours \& Company Inc., Wilmington, DE) was also evaluated as a fungicide drench for comparison. Each cucumber seed was placed in the seeding cavity of rock wool blocks and covered with vermiculite prior to addition of the appropriate amendment. Seedlings were grown under the same conditions as described above for evaluation of composts, and measurements of the percentage of dead and severely diseased plants (presence of a visible lesion), plant height (from the base of rock wool blocks to the growing tip), and fresh weights of shoots and leaves were recorded after 37 days from 10 plants per treatment. For control treatments, plants were inoculated with the pathogen alone or were not inoculated. The experiment was conducted three times.

Experimental design and statistical analysis. Crabshell experiments and bacterial seed treatment and fungicide experiments were conducted using a completely randomized design. Each crabshell experiment contained eight replicates of each treatment, and each bacterial seed treatment and fungicide experiment contained 10 replicates of each treatment. All other experiments were conducted using a randomized complete block design with five blocks and one replicated unit (containing two plants of every treatment) per block. Data from each trial were tested for experiment-by-treatment interactions and were combined if no significant interactions were found. Raw data from experiments evaluating the effect of composts and biological control agents were arcsine transformed to normalize data. All experiments were analyzed using analysis of variance (ANOVA). Treatment means of chitin experiments were separated using Fisher's least significant difference (LSD) test at $P \leq 0.05$ (SAS statistical analysis software, SAS Institute Inc., Cary, NC). Treatment means of all other experiments were separated using Tukey-Kramer honestly significant difference (HSD) test at $P$ $\leq 0.05$ (JMP IN 4 software (student version), SAS Institute) (53).

Semicommercial trials. Several treatments were evaluated for control of $F$. oxysporum f. sp. radicis-cucumerinum under semicommercial greenhouse propagation conditions. Cucumber seeds (cv. Mustang) were placed in the seeding cavity of $10 \times 10 \times 7 \mathrm{~cm}$ high rock wool blocks (1 seed per block). The cavities were filled with vermiculite, windrow-compost (15 $\mathrm{ml}$ ), or vermiculite amended with one of $T$. harzianum (RootShield Drench, $50 \mathrm{ml}$ per plant at $0.9 \mathrm{~g} / \mathrm{liter}$ ), S. griseoviridis (Mycostop, $50 \mathrm{ml}$ per plant at $1 \mathrm{~g} / \mathrm{liter}), G$. catenulatum (Prestop WP, $50 \mathrm{ml}$ per plant at $10 \mathrm{~g} /$ liter), or Benlate (benomyl, $12.5 \mathrm{ml}$ per plant at $50 \mu \mathrm{g}$ a.i./ml). After $48 \mathrm{~h}, 3 \mathrm{ml}$ of inoculum of $F$. oxysporum f. sp. radiciscucumerinum $\left(10^{6}\right.$ spores per $\left.\mathrm{ml}\right)$ was added to the seeding cavity of each rock wool block as a drench. The plants were treated a second time with the biocontrol agents and fungicide 10 days following seeding and reinoculated with the pathogen 2 days later. Each plant was contained in an individual plastic bag to avoid crosscontamination and was maintained on benches in a semicommercial propagation house (B.C. Ministry of Agriculture, Fisheries and Food, Abbotsford, B.C.) at $24 \pm$ $5^{\circ} \mathrm{C}$. The percentage of diseased plants (dead or showing symptoms) and the dry weight of each plant were recorded 33 days after seeding. Plant height was measured at weekly intervals starting 19 days after seeding. A disease severity index (DSI) modified from that described by Punja and Parker (51) was used to evaluate the effect of treatments on Fusarium root and stem rot. The DSI was used to assess the level of infection by incorporating both plant mortality and stunting of plants due to delayed symptoms. The DSI was calculated as: (\% plant mortality 19 days after seeding/19) + (\% plant mortality 33 days after seeding/33) $+[1-$ (height of surviving plants/height of nontreated control plants)]. The experiment was conducted four times: from June to July and July to August 2001, from August to September 2001, and from February to March 2002. Each semicommercial experiment consisted of a randomized complete block design with two blocks and five replicated units (each containing one plant of every treatment) per block. DSI values were analyzed using ANOVA, and means were separated using Tukey-Kramer HSD at $P \leq 0.05$. All tests of significance were done using JMP IN 4 software (SAS Institute).

\section{RESULTS}

Effect of inoculation time on disease development. A significant experimentby-treatment interaction was found among 
experiments; data presented represent the results from one experiment. The other two experiments showed similar trends. The addition of $F$. oxysporum f. sp. radiciscucumerinum to the seeding cavity of rock wool blocks resulted in the greatest number of dead plants when inoculum was added 1, 3, and 5 days following seeding (average mortality of 60, 70, and 80\%, respectively). There was a marked decrease in plant mortality when inoculum was added later than 5 days after seeding. Inoculation with $F$. oxysporum f. sp. radiciscucumerinum at 7 and 10 days following seeding resulted in $10 \%$ and $20 \%$ mortality, respectively (Fig. 2).

Effect of crab/shrimp shells. Following the addition of crab/shrimp shell chitin to the peat-based growing medium, the $\mathrm{pH}$ of the medium increased rapidly from 5.4 to 7.4 within 15 days, followed by a sharp decline to pH 5.1 after 40 days (Fig. 3). By comparison, the $\mathrm{pH}$ of the medium in the nonamended control pots rose gradually to $\mathrm{pH} 6.8$ after 40 days. The population levels of $F$. oxysporum $\mathrm{f}$. sp. radicis-cucumerinum in the chitinamended medium declined sharply from $4.5 \times$ $10^{5} \mathrm{CFU} / \mathrm{cm}^{3}$ to $1.4 \times 10^{5} \mathrm{CFU} / \mathrm{cm}^{3}$ after 40 days (Fig. 3). In the nonamended control, the pathogen populations increased over 25 days to a maximum of $6.0 \times 10^{5} \mathrm{CFU} / \mathrm{cm}^{3}$ and then declined to $2.0 \times 10^{5} \mathrm{CFU} / \mathrm{cm}^{3}$ by 40 days after amendment.

The growth rate and vigor of cucumber seedlings in chitin-amended medium were significantly enhanced over those in nonamended SM (Table 1, Fig. 4). In the presence of $F$. oxysporum f. sp. radiciscucumerinum, however, the percentage of symptomatic plants was significantly higher in the chitin-amended medium compared with the nonamended SM (Table 1), and plant height and shoot fresh weights were significantly reduced in the former versus the latter medium.

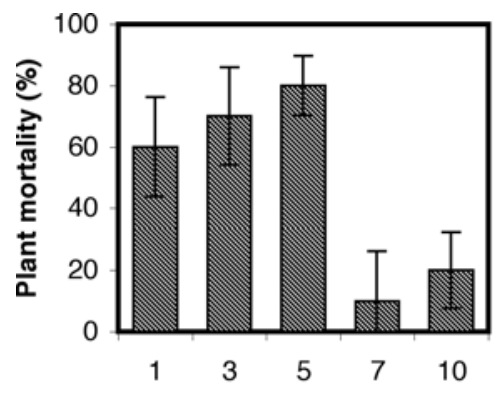

Time of inoculation (days after seeding',

Fig. 2. Effect of time of inoculation with Fusarium oxysporum f. sp. radicis-cucumerinum on development of root and stem rot of cucumber seedlings. Inoculum was applied at various times after seeds were planted, and plant mortality was recorded 37 days after inoculation. The experiment was conducted using a randomized complete block design with five blocks and one replicated unit (containing two plants of each treatment) per block. Results from one experiment are presented. Bars represent standard errors of the means.
Effect of composts. Data from the replications of each of the three experiments are presented together, as no significant experiment-by-treatment interactions were found $(P=0.811)$ among experiments. Greenhouse compost added to the seeding cavity of rock wool blocks resulted in a significant $(P \leq 0.05)$ reduction in plant mortality relative to nonamended blocks (Fig. 5). Plants receiving greenhouse compost followed by the addition of $F$. $o x$ ysporum f. sp. radicis-cucumerinum inoculum had an average mortality of $13.3 \%$ compared with $63.3 \%$ for plants receiving pathogen alone. The addition of windrowcomposted dairy solids and vermicomposted dairy solids to the rock wool block system also reduced plant mortality, but to a lesser extent than greenhouse compost (Fig. 5). Plant mortality averaged 33.3 and $36.7 \%$ for windrow-composted dairy solids and vermi-composted dairy solids, respectively. The addition of sterilized greenhouse compost to the seeding cavity of the rock wool block system did not significantly reduce plant mortality compared with the nonamended control (Fig. 5). Plants receiving the fungicide benomyl had the lowest mortality of all inoculated treatments, with an average of $10 \%$ of dead seedlings, which was not significantly different from the compost treatments or the noninoculated control. The addition of greenhouse compost to the seeding cavity of rock wool blocks gradually reduced populations of $F$. oxysporum $\mathrm{f}$.

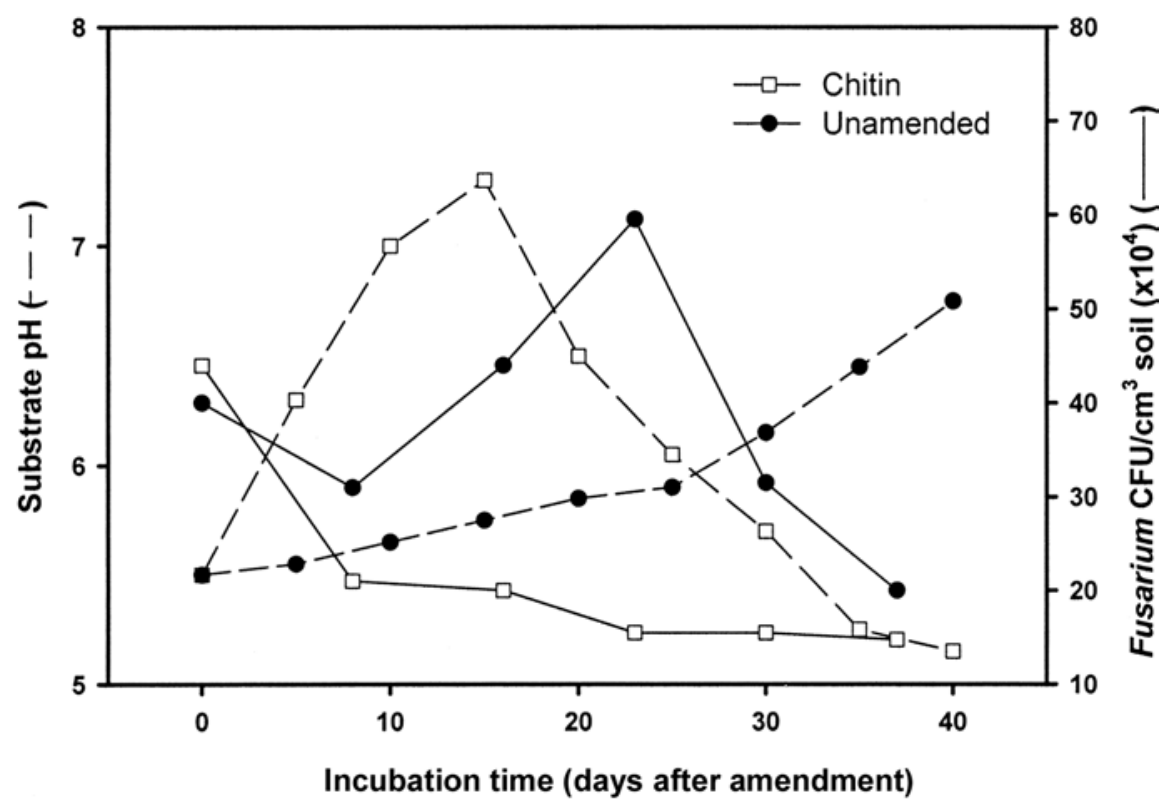

Fig. 3. Effect of crab/shrimp shells on changes in substrate $\mathrm{pH}$ and population levels of Fusarium oxysporum $\mathrm{f}$. sp. radicis-cucumerinum at various times following amendment. Sunshine Mix \#1 was amended at $4 \%(\mathrm{vol} / \mathrm{vol})$ with crab/shrimp shells and incubated at 20 to $23^{\circ} \mathrm{C}$. Pathogen populations were measured by plating a dilution series onto Komada's agar medium (27) (three replicates per mean).

Table 1. Effects of amendment of peat-based growing medium with crab/shrimp shell chitin on growth of cucumber plants and incidence of Fusarium root and stem rot

\begin{tabular}{|c|c|c|c|}
\hline \multirow[b]{2}{*}{ Amendment to growing medium $y$} & \multicolumn{3}{|c|}{ Plant growth ${ }^{x}$} \\
\hline & $\begin{array}{c}\text { Height } \\
(\mathrm{cm})^{\mathrm{z}}\end{array}$ & $\begin{array}{l}\text { Shoot fresh } \\
\text { weight }(g)^{\mathrm{z}}\end{array}$ & $\begin{array}{l}\text { Symptomatic } \\
\text { plants }(\%)^{\mathrm{z}}\end{array}$ \\
\hline Control & $14.7 \mathrm{~b}$ & $10.6 \mathrm{~b}$ & $0 \mathrm{c}$ \\
\hline Crab/shrimp shells & $22.6 \mathrm{a}$ & $17.3 \mathrm{a}$ & $0 \mathrm{c}$ \\
\hline $\begin{array}{l}\text { Fusarium oxysporum f. sp. radicis- } \\
\text { cucumerinum }\end{array}$ & $11.4 \mathrm{c}$ & $9.1 \mathrm{~b}$ & $38 \mathrm{~b}$ \\
\hline $\begin{array}{l}\mathrm{SM}+\text { crab/shrimp shells } \\
+ \text { F. oxysporum f. sp. radicis-cucur }\end{array}$ & $8.9 \mathrm{~d}$ & $6.4 \mathrm{c}$ & 79 a \\
\hline
\end{tabular}

${ }^{\mathrm{x}}$ Data are means from eight replicate plants; the experiment was a completely randomized design and was repeated twice. Data are the pooled results of three experiments. Measurements were made 24 days after seeding. Plants were maintained in a growth chamber with a 16-h photoperiod and temperature of $24 \pm 2^{\circ} \mathrm{C}$.

${ }^{y}$ Growing medium consisted of Sunshine Mix \#1 (SM) medium containing 70 to $80 \%$ Canadian sphagnum peat moss, perlite, dolomitic limestone, gypsum, and wetting agent. Crab/shrimp shells were added to the growing medium at a rate of $4 \%$ (vol/vol). Inoculum of Fusarium oxysporum $\mathrm{f}$. sp. radicis-cucumerinum was added to the growing medium 3 days after the initial amendment, and pregerminated cucumber seeds were added to the growing medium 1 day later.

${ }^{\mathrm{z}}$ Means followed by different letters are significantly different according to Fisher's least significant difference test $(P \leq 0.05)$. 
sp. radicis-cucumerinum recovered from sawdust samples compared with nonamended SM. From 2 to 3 weeks after seeding, the decline in populations of $F$. oxysporum f. sp. radicis-cucumerinum recovered from the sawdust in treatments receiving compost and from the sawdust in treatments receiving the pathogen alone was similar. From 3 to 4 weeks after seeding, however, the population of the pathogen recovered from compost-amended plants declined by $68 \%$, whereas the population of the pathogen recovered from nonamended plants declined by only $22 \%$ over the same time period. The population of $F$. oxysporum f. $\mathrm{sp}$. radiciscucumerinum recovered from compostamended plants declined by an additional $15 \%$ from 4 to 5 weeks after seeding, while the population of $F$. oxysporum f. sp. radicis-cucumerinum recovered from nonamended plants increased by $1 \%$.

Effect of seed treatment with bacteria or fungicide. The application of $P$. chlororaphis strain 63-28 or thiram to cucumber seeds 4 days following inoculation of the seeds with $F$. oxysporum f. sp. radiciscucumerinum significantly reduced plant

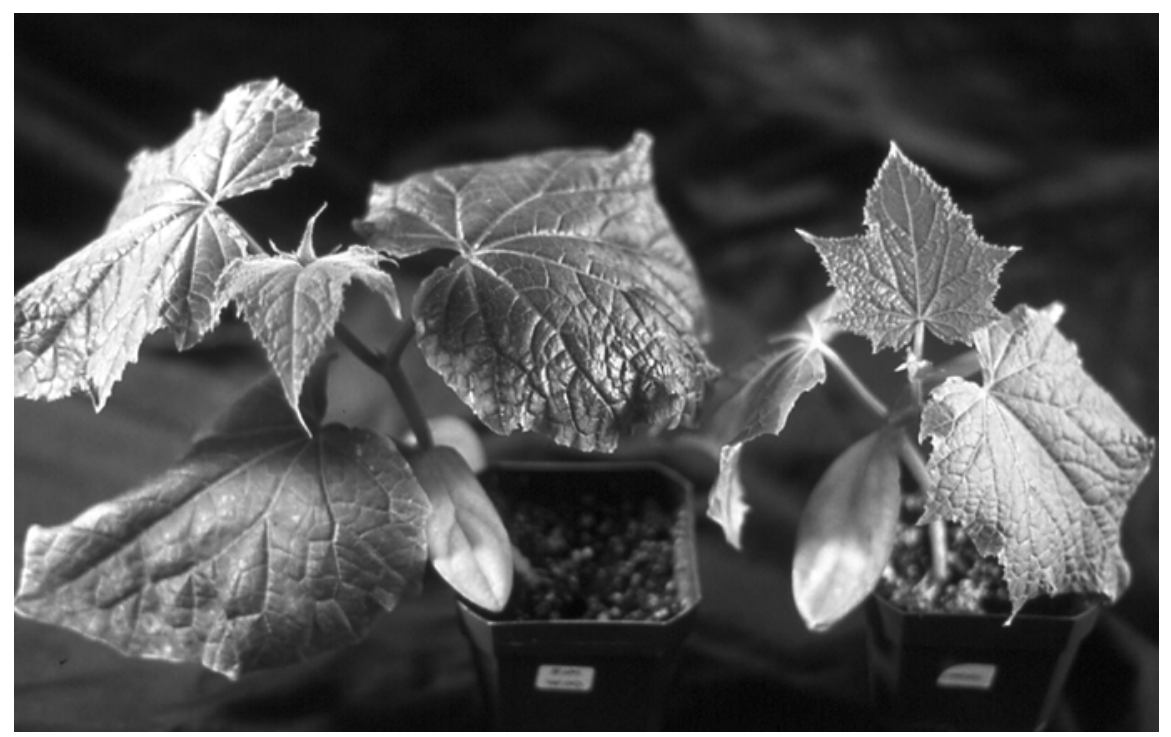

Fig. 4. Growth response of cucumber seedlings grown in Sunshine Mix \#1 amended with $4 \%$ chitin (left) compared with control plants (right). Photo was taken 18 days after seeding. Plants grown in a chitin-amended medium were found to be more susceptible to Fusarium oxysporum f. sp. radiciscucumerinum.

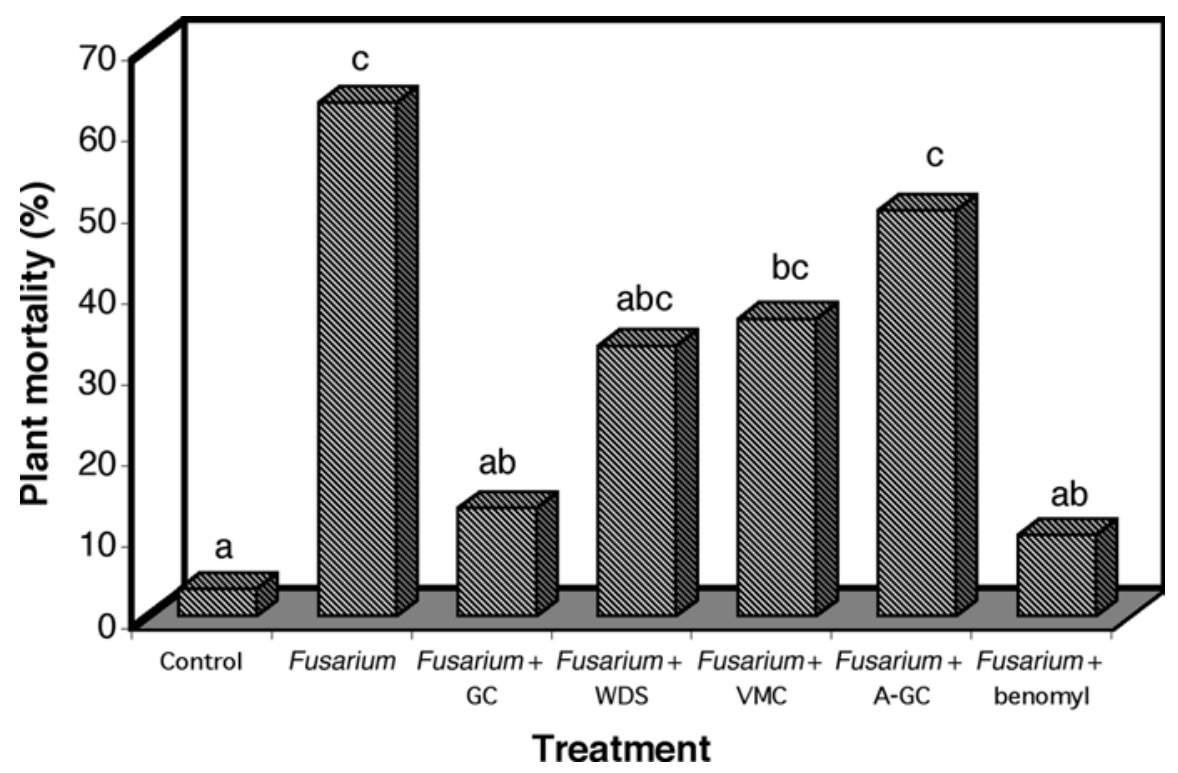

Fig. 5. Effect of greenhouse compost (GC), windrow-composted dairy solids (WDS), vermicomposted dairy solids (VMC), autoclaved greenhouse compost (A-GC), and the fungicide benomyl (Benlate, $50 \%$ a.i.) on mortality of cucumber seedlings caused by Fusarium oxysporum f. sp. radiciscucumerinum. Columns with different letters are significantly different $(P \leq 0.05$, Tukey Kramer honestly significant difference test). Data are pooled results of three experiments. Each experiment was conducted using a randomized complete block design with five blocks and one replicated unit (containing two plants of each treatment) per block. mortality at 17 and $24^{\circ} \mathrm{C}$ (Fig. 6). Application of the bacterium or the fungicide to seeds followed by planting into pathogeninfested potting mix also significantly reduced mortality caused by $F$. oxysporum f. sp. radicis-cucumerinum at $24^{\circ} \mathrm{C}$, but not at $17^{\circ} \mathrm{C}$. At $17^{\circ} \mathrm{C}$, control plants grew more slowly and appeared stunted.

Evaluation of commercial biological control agents. Data from the replications of each of the three experiments are presented together, as no significant experiment-by-treatment interactions were found $(P=0.8036)$ among experiments. Noninoculated control treatments that did not germinate (average of $10 \%$ over three trials) were excluded from analysis. The biological control agent $G$. catenulatum (Prestop WP and Prestop Mix) added to the seeding cavity of rock wool blocks followed $24 \mathrm{~h}$ later by inoculum of $F$. $o x$ ysporum f. sp. radicis-cucumerinum significantly $(P \leq 0.05)$ reduced the percentage of diseased plants compared with controls receiving the pathogen only (Fig. 7), and provided a degree of control

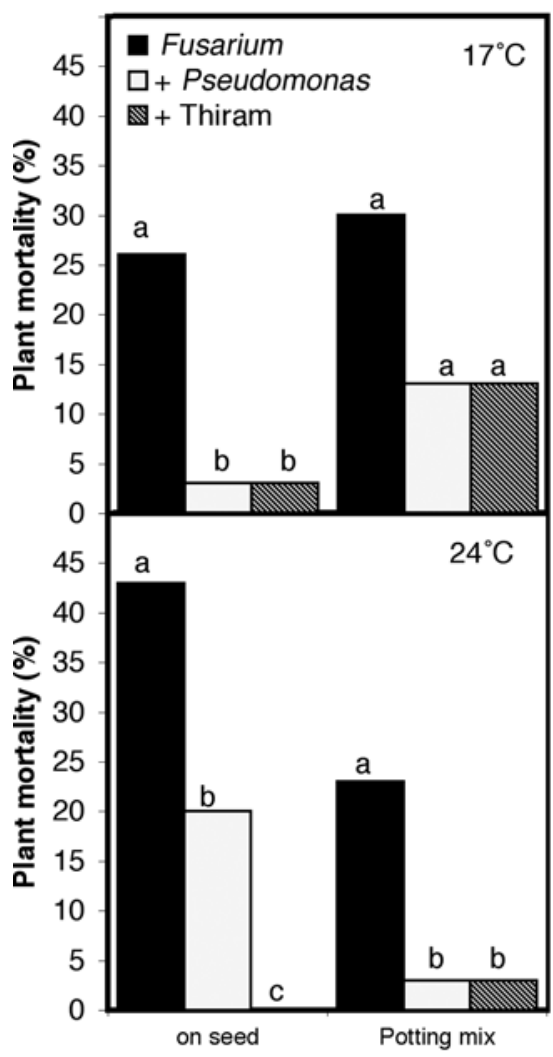

Method of Fusarium application

Fig. 6. Effect of Pseudomonas chlororaphis strain 63-28 or thiram (applied to seeds) on mortality of cucumber seedlings caused by Fusarium oxysporum f. sp. radiciscucumerinum inoculated onto the seeds or into potting medium (Sunshine Mix \#1) at 24 and $17^{\circ} \mathrm{C}$. Means are the average of 10 replications, and the experiment was conducted twice. Means followed by the same letter within each set of treatments are not significantly different $(P \leq 0.05$, Tukey Kramer honestly significant difference test). 
that was not significantly different from noninoculated control plants or from plants receiving the fungicide benomyl. Application of Mycostop reduced the percentage of disease caused by $F$. oxysporum f. sp. radicis-cucumerinum, but the reduction in disease was not significantly different from the inoculated control treatment. Similarly, treatment with RootShield Drench did not reduce disease. The application of SoilGard also did not provide a significant reduction in diseased plants compared with inoculated control plants, when evaluated in separate trials (data not shown).

Semicommercial trials. For the first two trials in this study (combined as trial 1 since no significant experiment-bytreatment interactions were found among experiments $[P=0.1408]$ ), the DSI was low for all treatments, including plants inoculated with $F$. oxysporum $\mathrm{f}$. sp. radiciscucumerinum alone, and statistical analysis did not separate out any biological or fungicide treatments from the controls. Greenhouse temperatures were high $\left(>28^{\circ} \mathrm{C}\right)$ during these two trials, and there was a low incidence of root and stem rot, resulting in low DSI values. In the fall/winter trials of 2001 and 2002 (trials 2 and 3), disease severity was greater overall and all treatments significantly reduced DSI compared with the inoculated control treatment (Table 2). Data from trials 2 and 3 are presented separately, as a significant experiment-by-treatment interaction was found among experiments, despite similar results. In trial 2, the DSI ranged from 0.00 for benomyl to 0.81 for Mycostop, and plants inoculated with $F$. oxysporum f. sp. radicis-cucumerinum had a DSI of 3.27 . In trial 3, all treatments significantly reduced disease compared with the inoculated control treatment. The compost treatment visually enhanced plant growth compared with the noninoculated control treatment, although this difference was not significant (Table 2). A comparison of the Prestop-treated (with Fusarium) and Fusarium-alone plants from trial 3 is shown in Figure 8.

\section{DISCUSSION}

The growing substrate widely used in commercial greenhouse production of cucumber (rock wool) presents both challenges and opportunities for the management of plant diseases. Rock wool is an inert substrate, which is initially free of microorganisms (50); therefore, introduced pathogens such as $F$. oxysporum f. sp. radicis-cucumerinum have universal access to the substrate and plant roots, and can grow and sporulate profusely $(40,51)$. In contrast, under field conditions, naturally occurring microorganisms have the potential to preclude the proliferation of $F$. $o x$ ysporum f. $\mathrm{sp}$. radicis-cucumerinum in soil, reducing its ability to compete for host roots, e.g., in suppressive soils $(6,45)$. However, under greenhouse production, the controlled environmental conditions, high value of the crops, and the lack of naturally occurring microorganisms with potential to out-compete introduced biological control agents for substrate niches, makes the implementation of biological control agents potentially more feasible $(46,50)$. In this study, we have demon-

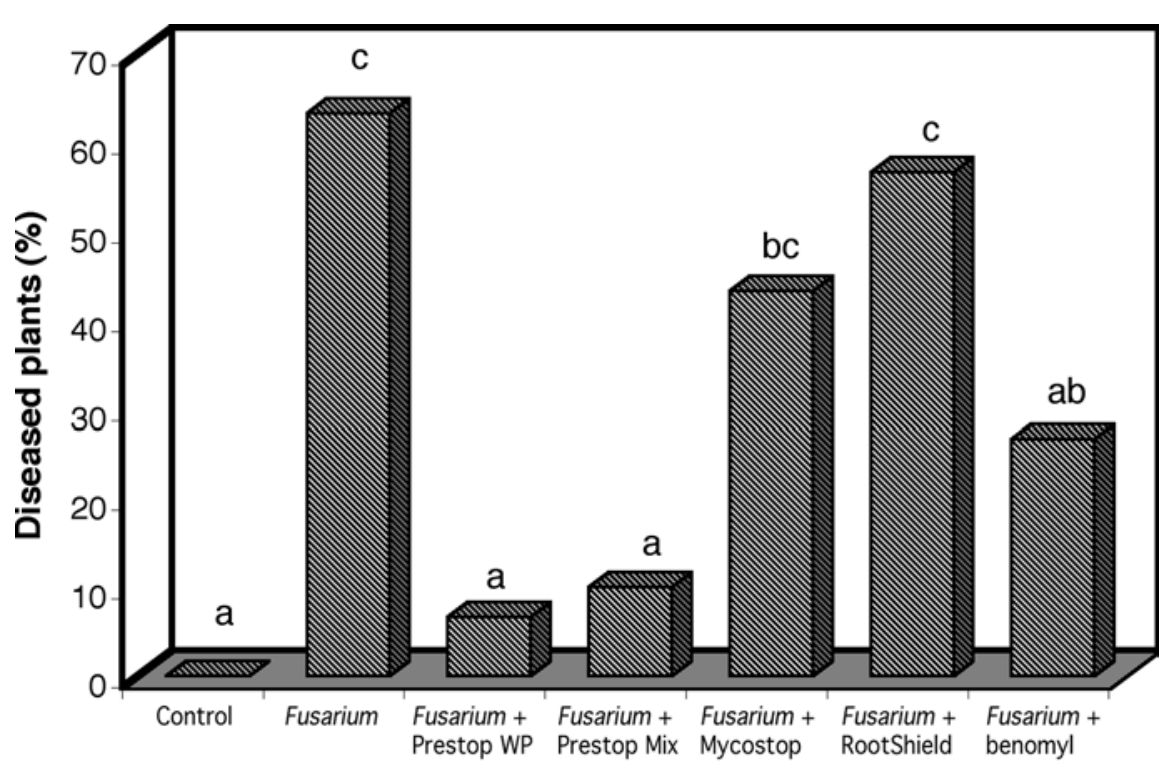

Treatment

Fig. 7. Effect of biological control agents Prestop WP and Prestop Mix (Gliocladium catenulatum), Mycostop (Streptomyces griseoviridis), RootShield Drench (Trichoderma harzianum), and the fungicide benomyl (Benlate, $50 \%$ a.i.) on mortality of cucumber seedlings caused by Fusarium oxysporum f. sp. radicis-cucumerinum. Bars followed by different letters are significantly different $(P \leq$ 0.05 , Tukey Kramer honestly significant difference test). Data are the pooled results of three experiments. Each experiment was conducted using a randomized complete block design with five blocks and one replicated unit (containing two plants of each treatment) per block.

Table 2. Effect of three biological control agents and windrow-composted dairy solids on development of Fusarium oxysporum f. sp. radicis-cucumerinum on cucumber seedlings grown under semicommercial propagation conditions

\begin{tabular}{|c|c|c|}
\hline \multirow[b]{3}{*}{ Treatment $^{\mathrm{z}}$} & \multicolumn{2}{|c|}{ DSI $^{x}$} \\
\hline & Trial $2^{y}$ & Trial $3^{y}$ \\
\hline & Aug.-Sept. 2001 & Feb.-Mar. 2002 \\
\hline Uninoculated control & $0.00 \mathrm{a}$ & $0.00 \mathrm{ab}$ \\
\hline F. oxysporum f. sp. radicis-сиситеrinum only & $3.27 \mathrm{c}$ & $1.31 \mathrm{~d}$ \\
\hline Prestop $\mathrm{WP}+F$. oxysporum f. sp. radicis-cucumerinum & $0.43 \mathrm{ab}$ & $0.21 \mathrm{c}$ \\
\hline $\begin{array}{l}\text { RootShield Drench }+F \text {. oxysporum f. sp. radicis- } \\
\text { cucumerinum }\end{array}$ & $0.59 \mathrm{ab}$ & $0.16 \mathrm{c}$ \\
\hline Mycostop $+F$. oxysporum f. sp. radicis-cucumerinum & $0.81 \mathrm{~b}$ & $0.05 \mathrm{ab}$ \\
\hline Compost $+F$. oxysporum f. sp. radicis-cucumerinum & $0.29 \mathrm{ab}$ & $-0.04 \mathrm{a}$ \\
\hline Benomyl $+F$. oxysporum f. sp. radicis-cucumerinum & $0.00 \mathrm{a}$ & $0.06 \mathrm{~b}$ \\
\hline
\end{tabular}

${ }^{\mathrm{x}}$ Disease severity index (DSI) was calculated as described in Materials and Methods and was used to assess level of infection due to $F$. oxysporum f. sp. radicis-cucumerinum by incorporating both plant mortality and stunting of plants due to delayed symptoms.

${ }^{y}$ Means presented are the average of 10 plants; each experiment was a randomized complete design with two blocks and five replicated units of each treatment per block. Means followed by the same letter are not significantly different $(P \leq 0.05$, Tukey Kramer honestly significant difference test) (53). Trial 1 (incorporating combined data from two trials) is not included, as there were no significant differences among treatments.

${ }^{\text {z }}$ Prestop WP (10.0 g/liter), RootShield Drench $(0.9 \mathrm{~g} /$ liter $)$, or Mycostop (1.0 g/liter) was added twice (at seeding and 10 days later) as a drench at $50 \mathrm{ml}$ per block to seeding cavity of rock wool blocks containing cucumber seeds covered with $15 \mathrm{ml}$ of vermiculite. Compost (windrow-composted dairy solids, prepared as described in Materials and Methods) was added ( $15 \mathrm{ml})$ directly to seeding cavity of blocks at seeding. Benomyl $(50 \mu \mathrm{g}$ a.i./ml) was added as a drench to blocks at $12.5 \mathrm{ml}$ per block. Inoculum of $F$. oxysporum $\mathrm{f}$. sp. radicis-cucumerinum $\left(3 \mathrm{ml}\right.$ per block at $10^{6}$ spores per $\mathrm{ml}$ ) was added as a drench to the seeding cavity of each block $48 \mathrm{~h}$ after seeding and again 10 days later. 
ize composts to control plant diseases (24). Our results demonstrated that greenhouse compost and windrow-composted dairy solids, but not vermi-composted dairy solids, significantly reduced development of Fusarium root and stem rot on cucumber when applied to the seeding cavity of rock wool blocks at seeding time. When the greenhouse compost was autoclaved, the disease-suppressive activity was significantly reduced, suggesting that competing microorganisms played a role in suppression of the pathogen, and substantiating previous reports on the involvement of microbes in disease suppression by composts (23). Species of Trichoderma, Gliocladium, Pseudomonas, and Streptomyces have all been recovered from composts (23), and these and other microbes have been reported to suppress pathogenic Fusarium spp. (31). The diseasesuppressive nature of composts is a wellstudied phenomenon, involving a number of general and specific mechanisms (24). Spores of $F$. oxysporum f. sp. radiciscucumerinum may have been prevented from germinating and infecting the plants by any of these mechanisms, but this was not investigated in this study. In addition, application of windrow-composted dairy solids under semicommercial conditions was found to promote growth of cucumber seedlings, probably in association with the release of nitrogen and other nutrients from this compost (8). Analysis of windrowcomposted dairy solids showed it had a $\mathrm{C}: \mathrm{N}$ ratio of $21: 1$, and fungal and bacterial counts of $176 \times 10^{6}$ and $105 \times 10^{9} \mathrm{CFU} / \mathrm{g}$ dry weight, respectively (26). Inoculum levels of $F$. oxysporum f. sp. radiciscucumerinum were found to be lower in compost-amended treatments than in

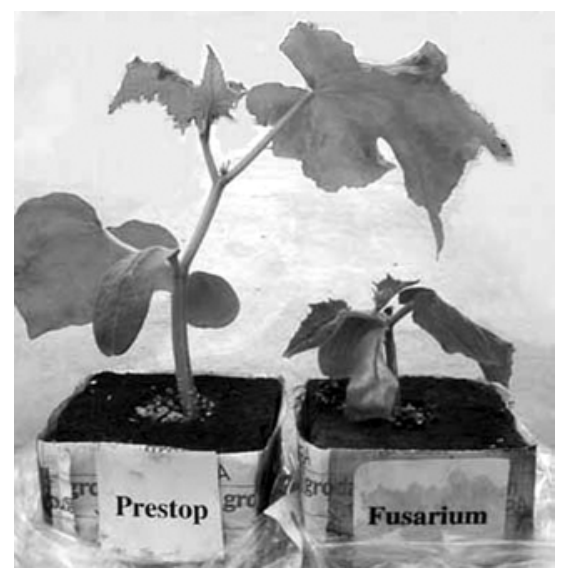

Fig. 8. Comparison of growth of cucumber plants in semicommercial greenhouse propagation trials. Plant on the left received Prestop WP (Gliocladium catenulatum, $50 \mathrm{ml}$ per block at $10.0 \mathrm{~g} /$ liter) at seeding time and 10 days later, and was inoculated with Fusarium oxysporum f. sp. radicis-cucumerinum 2 days after seeding and again 10 days later. Plant on the right was inoculated with $F$. oxysporum $\mathrm{f}$. sp. radicis-cucumerinum alone. Photograph was taken 23 days after seeding. nonamended treatments in this study, possibly as a result of microbial competition. While composts are variable in their biological and disease-suppressive activity, the results from this study demonstrated the potential use of composts in greenhouse production systems utilizing rock wool as the growth medium. Enhanced disease-suppression of rock wool due to gradual colonization by indigenous microflora was shown to suppress development of Pythium root and crown rot of cucumber (50). Composts may provide an alternate approach through which to more rapidly enhance the suppressiveness of rock wool to diseases. Amendment of compost with specific biological control agents was recently shown to enhance suppressiveness toward Fusarium crown and root rot of tomato (49) and represents another potential strategy for suppressing Fusarium root rot and stem rot of cucumber. Additional studies evaluating combinations of biological control agents with composts are warranted.

Amendment of the peat-based growing medium used in this study with crab/shrimp shell chitin prior to seeding significantly enhanced plant growth in the noninoculated control treatment, but in the presence of $F$. oxysporum f. sp. radiciscucumerinum, these plants were more susceptible to infection by the pathogen compared with plants in the nonamended treatment. An analysis of the crab/shrimp shells revealed the nitrogen content was $6.4 \%$ and the calcium content was $2 \%$. In soil, breakdown of chitin present in the crab/shrimp shells releases ammonia (21), which probably accounts for the marked rise in $\mathrm{pH}$ and growth stimulation observed in this study due to the additional nitrogen provided to the plants. A gradual increase in the population of chitinolytic bacteria and actinomycete populations has also been reported to occur in soil amended with chitin (7). Fertilization with ammonium-nitrogen, however, was reported to increase the susceptibility of tomato to $F$. oxysporum f. sp. radicis-lycopersici (15), and the results from our study support this, as observed with the enhanced susceptibility of cucumber to $F$. oxysporum f. sp. radicis-cucumerinum. The benefit of chitin amendment to soil for the control of several fungal pathogens, including Fusarium spp. $(7,9,20,21,42)$, was not observed for Fusarium root and stem rot of cucumber in this study, even though pathogen survival was reduced by chitin amendment to some extent. A delay in seeding until 40 days after amendment, at which time $\mathrm{pH}$ would have stabilized after ammonia release, pathogen populations would be reduced, and potentially antagonistic organisms increased in numbers, may provide some control of Fusarium root and stem rot of cucumber.

Several commercially available biological control agents evaluated in this study suppressed Fusarium root and stem rot of cucumber. In growth room trials on seedlings, only G. catenulatum (Prestop WP and Prestop Mix) reduced disease to the same level obtained with the fungicide benomyl. These studies were conducted under high disease pressure, with an average mortality of $63 \%$ in nonamended but inoculated control seedlings. With excessive pathogen inoculum levels, biological control agents tend not to perform well $(6,45)$. Reid et al. $(52)$ similarly found that the efficacy of biological control agents against Fusarium crown and root rot of asparagus, caused by Fusarium proliferatum and $F$. oxysporum f. sp. asparagi, was influenced by disease pressure, and a significant reduction in disease was obtained with the biological control agents only when used at low disease pressure. In commercial propagation houses, $F$. oxysporum $\mathrm{f}$. $\mathrm{sp}$. radicis-cucumerinum causes 10 to $15 \%$ seedling death; under these conditions, biological control agents should demonstrate adequate efficacy. This was confirmed in the semicommercial propagation trials, where seedling mortality averaged $30 \%$ in the inoculated control treatment, and all the biocontrol agents tested suppressed the disease.

Monitoring of the survival of biocontrol agents following application was not done in this study. Other reports have shown that G. catenulatum and T. harzianum are good root colonizers $(22,30)$, while $S$. griseoviridis has reduced colonizing potential (44). RootShield Drench, Mycostop, and SoilGard did not provide significant control of Fusarium root and stem rot on cucumber seedlings at the recommended rates of application in the seedling assays of this study. Larkin and Fravel (31) also reported that neither RootShield nor SoilGard reduced the development of Fusarium wilt of tomato ( $F$. oxysporum f. sp. lycopersici) at 0.05 or $0.1 \%$; however, both biocontrol agents significantly reduced disease incidence at $0.2 \%$. In our seedling assays, a single application of the biocontrol agents was made at seeding time; perhaps an additional application or higher rates of application would be necessary to ensure adequate protection over a longer duration. In the semicommercial trials, two applications of each biocontrol agent made 10 days apart were found to be effective in controlling Fusarium root and stem rot of cucumber. In addition to the lower disease pressure in these trials compared with the growth room trials, nutrient availability may have enhanced biocontrol efficacy. $T$. harzianum is reported to require a nutrient or food source for optimum biocontrol efficacy (35). In our semicommercial trials, the rock wool blocks were irrigated regularly with nutrient solution to provide an almost constant nutrient source for the plants and for any potential microbial antagonists. In our growth room trials, nutrient availability may have been limited 
since fertilizer was applied three times per week, possibly limiting establishment of the biocontrol agents.

The DSI values for trials 2 and 3, conducted in the fall and winter seasons, respectively, were much greater than those obtained from trial 1 , conducted in the summer. This difference in DSI values may reflect the lower greenhouse temperatures (18 to $24^{\circ} \mathrm{C}$ ) that occurred during trials 2 and 3 compared with trial 1. Cucumbers are reported to be most susceptible to Fusarium root and stem rot at temperatures between 17 and $24^{\circ} \mathrm{C} \mathrm{(51).} \mathrm{Results} \mathrm{of} \mathrm{these}$ trials illustrate the influence of seasonal growing conditions on disease development and biocontrol efficacy.

P. chlororaphis strain 63-28 and thiram each reduced incidence of Fusarium root and stem rot when pathogen-infested seed was treated and planted at 17 or at $24^{\circ} \mathrm{C}$. In pathogen-infested medium, seed treatment with the bacterium or fungicide was effective at controlling the disease at $24^{\circ} \mathrm{C}$ but not at $17^{\circ} \mathrm{C}$. Although seed dissemination of this pathogen has not been conclusively demonstrated, treatment of seed with bacteria or fungicide may reduce or prevent infection occurring at germination from inoculum near the root zone. Seed treatment was not evaluated as a delivery method for the other biological control agents, which were applied according to label specifications either as a drench or incorporated into the planting medium. Application of the biocontrol agents at seeding time was justified, as the time of inoculation studies demonstrated that cucumber seedlings were most susceptible to the pathogen during the first 5 days after seeding. The duration of protection afforded by the biocontrol agents was not determined.

A number of biological control agents have been reported to control diseases caused by $F$. oxysporum. These include nonpathogenic $F$. oxysporum strains $(2,16$, 17,31,32,38), Penicillium oxalicum (13), Pseudomonas fluorescens (12,14,16,18, 33,43), Streptomyces spp. (19,29,55), Trichoderma spp. $(11,31,41,59)$, and Bacillus subtilis $(28,59)$. Our research has demonstrated for the first time that the biocontrol agent $G$. catenulatum (Prestop) can significantly reduce disease caused by $F$. oxysporum f. sp. radicis-cucumerinum on cucumber and may have the potential for the control of Fusarium diseases of other greenhouse crops. McQuilken et al. (39) described the efficacy of G. catenulatum as a mycoparasite of Pythium ultimum and Rhizoctonia solani, and observed reduction of damping-off on bedding plants caused by these pathogens. Huang (25) described mycoparasitism of Fusarium species by $G$. catenulatum. This biological control agent has been reported to survive well in potting medium and produces hydrolytic enzymes in culture (39). The mechanism by which $G$. catenulatum suppressed $F$. oxysporum in this study is not known and warrants further investigation.

In Canada, Mycostop was the first biological control agent to be registered for use against root pathogens on greenhouse crops, and RootShield has recently (in 2002) received a registration $(4,5)$. This study has identified additional biological control agents that could be considered for registration. The greenhouse environment provides opportunities for the incorporation of biological control agents into commercial production systems. The data presented here illustrate the efficacy of composts and biocontrol agents, in particular G. catenulatum (Prestop WP), against Fusarium root and stem rot of cucumber grown in rock wool, and potentially for similar diseases on other greenhouse crops.

\section{ACKNOWLEDGMENTS}

Funding for this research was provided by the B.C. Greenhouse Growers Association, the Science Council of B.C. (GREAT Awards Program), and the Natural Sciences and Engineering Research Council of Canada (Biocontrol Network Program and University-Industry Research Partnerships Program). We thank K. Ng and R. Yip for providing assistance during the semicommercial trials, and the various companies for donating samples of biocontrol agents.

\section{LITERATURE CITED}

1. Agrios, G. N. 1997. Plant Pathology. 4th ed. Academic Press Ltd., San Diego, CA.

2. Alabouvette, C., Schippers, B., Lemanceau, P., and Bakker, P. A. 1998. Biological control of Fusarium wilts. Pages 15-36 in: PlantMicrobe Interactions and Biological Control. G. J. Boland and L. D. Kuykendall, eds. Marcel Dekker Inc., New York.

3. Anonymous. 1996. Greenhouse Vegetable Production Guide for Commercial Growers. British Columbia Ministry of Agriculture, Fisheries and Food, Victoria, B.C.

4. Anonymous. 1999. First ever biological pesticide for use in greenhouses approved through user requested minor use registration. Pest Manage. News 11(3-4):10.

5. Anonymous. 2002. RootShield Biological Fungicide Trichoderma harzianum Rifai strain KRL-AG2 Pest Management Regulatory Agency Regulatory Note. Online, publication REG2002-01.

6. Baker, K. F., and Cook, R. J. 1984. Biological Control of Plant Pathogens. American Phytopathological Society, St. Paul, MN.

7. Bell, A. A., Hubbard, J. C., Liu, L., Davis, R. M., and Subbarao, K. V. 1998. Effects of chitin and chitosan on the incidence and severity of Fusarium yellows of celery. Plant Dis. 82:322-328.

8. Boulter, J. I., Boland, G. J., and Trevors, J. T. 2000. Compost: A study of the development process and end-product potential for suppression of turfgrass disease. World J. Microbiol. 16:115-134

9. Buxton, E. W., Khalifa, O., and Ward, V. 1965. Effect of soil amendment with chitin on pea wilt caused by Fusarium oxysporum f. sp. pisi. Ann. Appl. Biol. 55:83-88.

10. Chef, D. G., Hoitink, H. A. J., and Madden, L. V. 1983. Effects of organic components in container media on suppression of Fusarium wilt of flax. Phytopathology 73:279-281.

11. Datnoff, L. E., Nemec, S., and Pernezny, K. 1995. Biological control of Fusarium crown and root rot of tomato in Florida using Trichoderma harzianum and Glomus intraradices. Biol. Contr. 5:427-431.
12. deBoer, M., vanderSluis, I., vanLoon, L. C. and Bakker, P. A. H. M. 1999. Combining fluorescent Pseudomonas spp. strains to enhance suppression of Fusarium wilt of radish. Eur. J. Plant Pathol. 105:201-210.

13. DeCal, A., Garcia-Lepe, R., Pascual, S., and Melgarejo, P. 1999. Effects of timing and method of application of Penicillium oxalicum on efficacy and duration of control of Fusarium wilt of tomato. Plant Pathol. 48:260-266.

14. Duffy, B. K., and Defago, G. 1997. Zinc improves biocontrol of Fusarium crown and root rot of tomato by Pseudomonas fluorescens and represses the production of pathogen metabolites inhibitory to bacterial antibiotic biosynthesis. Phytopathology 87:1250-1257.

15. Duffy, B. K., and Defago, G. 1999. Macroand microelement fertilizers influence the severity of Fusarium crown and root rot of tomato in a soilless production system. HortScience 34:287-291.

16. Duijff, B. J., Pouhair, D., Olivain, C., Alabouvette, C., and Lemanceau, P. 1998. Implication of systemic induced resistance in the suppression of Fusarium wilt of tomato by Pseudomonas fluorescens WCS417 $\mathrm{r}$ and by nonpathogenic Fusarium oxysporum Fo47. Eur. J. Plant Pathol. 104:903-910.

17. Fuchs, J.-G., Moenne-Loccoz, Y., and Defago, G. 1997. Nonpathogenic Fusarium oxysporum strain Fo47 induces resistance to Fusarium wilt in tomato. Plant Dis. 81:492496.

18. Gagne, S., Dehbi, L., LeQuere, D., Cayer, F., Morin, J.-L., Lemay, R., and Fournier, N. 1993. Increase of greenhouse tomato fruit yield by plant growth promoting rhizobacteria (PGPR) inoculated into the peat-based growing media. Soil Biol. Biochem. 25:269-272.

19. Hammad, A. M. M., and El-Mohandes, M. A O. 1999. Controlling Fusarium wilt disease of cucumber plants via antagonist microorganisms in free and immobilized states. Microbiol. Res. 154:113-117.

20. Hampson, M. C., and Coombes, J. W. 1991. Use of crabshell meal to control potato wart in Newfoundland. Can. J. Plant Pathol. 13:97105.

21. Hampson, M. C., and Coombes, J. W. 1995. Reduction of potato wart disease with crushed crabshell: Suppression or eradication? Can. J. Plant Pathol. 17:69-74.

22. Harman, G. E. 2000. Myths and dogmas of biocontrol: Changes in perceptions derived from research on Trichoderma harzianum $\mathrm{T}$ 22. Plant Dis. 84:377-393.

23. Hoitink, H. A. J., Krause, M. S., and Han, D. Y. 2001. Spectrums and mechanisms of plant disease control with composts. Pages 263-273 in: Compost Utilization in Horticultural Cropping Systems. P. J. Stoffella and B. A. Kahn, eds. Lewis Publishers, Boca Raton, FL.

24. Hoitink, H. A. J., Stone, A. G., and Han, D. Y. 1997. Suppression of plant diseases by composts. HortScience 32:184-187.

25. Huang, H. C. 1978. Gliocladium catenulatum: Hyperparasite of Sclerotinia sclerotiorum and Fusarium species. Can. J. Bot. 56:2243-2256.

26. Kannangara, T., Utkhede, R. S., Paul, J. W., and Punja, Z. K. 2000. Effects of mesophillic and thermophillic composts on suppression of Fusarium root and stem rot of greenhouse cucumber. Can. J. Microbiol. 46:1021-1028

27. Komada, H. 1975. Development of selective medium for quantitative isolation of Fusarium oxysporum from natural soil. Rev. Plant Prot. Res. 8:114-125.

28. Kumar, B. S. D. 1999. Fusarial wilt suppression and crop improvement through two rhizobacterial strains in chickpea growing in soils infested with Fusarium oxysporum f. sp. ciceris. Biol. Fertil. Soils 29:87-91. 
29. Lahdenpera, M. L. 1987. The control of Fusarium wilt on carnation with a Streptomyces preparation. Acta Hortic. 216:85-92.

30. Lahdenpera, M. L. 2000. The mode of action of Gliocladium catenulatum J1446. Kemira Agro Oy, Espoo Research Centre, Finland.

31. Larkin, R. P., and Fravel, D. R. 1998. Efficacy of various fungal and bacterial biocontrol organisms for control of Fusarium wilt of tomato. Plant Dis. 82:1022-1028.

32. Larkin, R. P., Hopkins, D. L., and Martin, F. N. 1996. Suppression of Fusarium wilt of watermelon by nonpathogenic Fusarium oxysporum and other microorganisms recovered from a disease-suppressive soil. Phytopathology 86:812-819.

33. Leeman, M., van Pelt, J. A., Hendrickx, M. J., Scheffer, R. J., Bakker, P. A. H. M., and Schippers, B. 1998. Biocontrol of Fusarium wilt of radish in commercial greenhouse trials by seed treatment with Pseudomonas fluorescens WCS374. Phytopathology 85:13011305.

34. Lemanceau, P., and Alabouvette, C. 1991. Biological control of Fusarium diseases by fluorescent Pseudomonas and non-pathogenic Fusarium. Crop Prot. 10:279-286.

35. Lewis, J. A., and Papavizas, G. C. 1984. A new approach to stimulate population proliferation of Trichoderma species and other potential biocontrol fungi introduced into natural soils. Phytopathology 74:1240-1244.

36. Liu, L., Kloepper, J. W., and Tuzun, S. 1995. Induction of systemic resistance in cucumber by plant growth-promoting rhizobacteria: $\mathrm{Du}-$ ration of protection and effect of host resistance on protection and root colonization. Phytopathology 85:1064-1068.

37. Lumsden, R. D., Lewis, J. A., and Milner, P. D. 1983. Effect of composted sewage sludge on several soilborne pathogens and diseases. Phytopathology 73:1543-1548.

38. Mandeel, Q., and Baker, R. 1991. Mechanisms involved in biological control of Fusarium wilt of cucumber with strains of nonpathogenic Fusarium oxysporum. Phytopathology 81:462-469.

39. McQuilken, M. P., Gemmell, J., and Lahdenpera, M. L. 2001. Gliocladium catenulatum as a potential biological control agent of damping-off in bedding plants. J. Phytopathol. 149:171-178.

40. Mihuta-Grimm, L., Erb, W. A., and Rowe, R. C. 1990. Fusarium crown and root rot of tomato in greenhouse rock wool systems: Sources of inoculum and disease management with benomyl. Plant Dis. 74:996-1002.

41. Mishra, P. K., Mukhopadhyay, A. N., and Fox, R. T. V. 2000. Integrated and biological control of gladiolus corm rot and wilt caused by Fusarium oxysporum f. sp. gladioli. Ann. Appl. Biol. 137:361-364.

42. Mitchell, R., and Alexander, M. 1961. Chitin and the biological control of Fusarium diseases. Plant Dis. Rep. 45:487-490.

43. M'piga, P., Belanger, R. R., Paulitz, T. C., and Benhamou, N. 1997. Increased resistance to Fusarium oxysporum f. sp. radicis-lycopersici in tomato plants treated with the endophytic bacterium Pseudomonas fluorescens strain 63-28. Physiol. Mol. Plant Pathol. 50:301320 .

44. Nemec, S., Datnoff, L. E., and Strandberg, J. 1996. Efficacy of biocontrol agents in planting mixes to colonize plant roots and control root diseases of vegetables and citrus. Crop Prot. 15:735-742.

45. Paulitz, T. C. 1996. Biological control of root pathogens in soilless and hydroponic systems. HortScience 32:193-196.

46. Paulitz, T. C., and Belanger, R. R. 2001. Biological control in greenhouse systems. Annu. Rev. Phytopathol. 39:103-133.

47. Pavlou, G. C., Vakalounakis, D. J., and Ligoxigakis, E. K. 2002. Control of root and stem rot of cucumber, caused by Fusarium oxysporum f. sp. radicis-cucumerinum, by grafting onto resistant rootstocks. Plant Dis. 86:379-382.

48. Pera, J., and Calvet, C. 1989. Suppression of Fusarium wilt of carnation in a composted pine bark and a composted olive pumice. Plant Dis. 73:699-700.

49. Pharand, B., Carisse, O., and Benhamou, N. 2002. Cytological aspects of compostmediated induced resistance against Fusarium crown and root rot in tomato. Phytopathology 92:424-438.
50. Postma, J., Willemsen-de Klein, J. E. I. M., and van Elsas, J. D. 2000. Effect of the indigenous microflora on the development of root and crown rot caused by Pythium aphanidermatum in cucumber grown on rockwool. Phytopathology 90:125-133.

51. Punja, Z. K., and Parker, M. 2000. Development of Fusarium root and stem rot, a new disease on greenhouse cucumbers in British Columbia caused by Fusarium oxysporum $\mathrm{f}$. sp. radicis-cucumerinum. Can. J. Plant Pathol. 22:349-363.

52. Reid, T. C., Hausbeck, M. K., and Kizilkaya, K. 2002. Use of fungicides and biological controls in the suppression of Fusarium crown and root rot of asparagus under greenhouse and growth chamber conditions. Plant Dis. 86:493-498.

53. Sall, J., Lehman, A., and Creighton, L. 2001. JMP Start Statistics: A Guide to Statistics and Data Analysis Using JMP and JMP IN Software 2nd ed. SAS Institute Inc. Cary, NC.

54. Serra-Wittling, C., Houot, S., and Alabouvette, C. 1996. Increased soil suppressiveness to Fusarium wilt of flax after addition of municipal solid waste compost. Soil Biol. Biochem. 28:1027-1214.

55. Singh, P. P., Shin, Y. C., Park, C. S., and Chung, Y. R. 1999. Biological control of Fusarium wilt of cucumber by chitinolytic bacteria. Phytopathology 89:92-99.

56. Szczech, M. M. 1999. Suppressiveness of vermicompost against Fusarium wilt of tomato. J. Phytopathol. 147:155-161.

57. Trillas-Gay, M. I., Hoitink, H. A. J., and Madden, L. V. 1986. Nature of suppression of Fusarium wilt of radish in a container medium amended with composted hardwood bark. Plant Dis. 70:1023-1027.

58. Vakalounakis, D. J. 1996. Root and stem rot of cucumber caused by Fusarium oxysporum f. sp. radicis-cucumerinum f. sp. nov. Plant Dis. 80:313-316.

59. Zhang, J., Howell, C. R., and Starr, J. L. 1996. Suppression of Fusarium colonization of cotton and Fusarium wilt by seed treatments with Gliocladium virens and Bacilllus subtilis. Biocontrol Sci. Technol. 6:175-187. 